\title{
Üniversite Öğrencilerinin Yaşlı Ayrımcılığıyla İlgili Tutumları: Keskin MYO Örneği
}

\author{
Atilla ALTUN ${ }^{1}$ ve Barıș DEMIREL ${ }^{2}$
}

\section{$\ddot{\mathrm{O} z}$}

İnsanlar bir araya geldiklerinde yaş, cinsiyet, rrk, din gibi faktörler bu birlikteliğin kalitesine ve sürekliliğine önemli derecede etki eder. Kadın ve erkeğin bir arada olduğu bir ortamda iletişimin boyutu, yaşlı ve genç bireylerin bir arada olduğu mekânlarla aynı değildir. Erkeklerin kadınlara, gençlerin yaşıllara, aynı din mensuplarının diğer dini gruplara karşı ayrımcllı gösterme durumu her zaman mevcuttur. Bu durum, cinsiyet, rrk, yaş vb. faktörlerin bireysel tutumları önemli derecede etkilediğinin bir göstergesidir. Buradan hareketle, bu araştırmada yüksekokul öğrencilerinin yaşlı ayrımcilığyla ilgili tutumları incelenmektedir. Veri toplama aracı olarak 10 sorudan oluşan "Kişisel Bilgi Formu" ile 23 sorudan oluşan "Yaşlı Ayrımcilğ̆ Tutum Ölçeği (YATÖ)" kullanılmışıı. Yapplan analizler sonucunda yaşlı ayrımcllğ̆ tutum ölçeğinden öğrencilerin aldığı puanların cinsiyet ve öğrenim görülen program gibi değişkenlere göre anlamlı farklılık gösterdiğgi $(\mathrm{p}<0.05)$ belirlenmiştir. Sonuç olarak bireylerle kurulan ilişki ve iletişimin temelinde tutumlar yer almaktadır. Olumlu tutumlara sahip olmak ve yaşlılara yönelik olumlu bir bakış açısına sahip olmak da bu nedenle önemlidir. Buradan hareketle, yaşlya yönelik yapılacak planlamalarda üniversite öğrencisi genç bireylerin yaşıllara ilişkin tutumlarının araştırılması, toplumsal temelde kuşaklar arası farklılıkların ortadan kaldırılması bağlamında geleceğe ışık tutacak bilgiler elde edilmesi açısından önemli bir gerekliliktir.

Anabtar Kelimeler: Ayrımcllık, Tutum Ölçeği, Üniversite Öğrencisi, Yaşlanma, Yaşlı

\section{Attitudes of University Students on Elderly Discrimination: The Case of Keskin} Vocational School

\begin{abstract}
When people come together, factors like age, gender, race, religion significantly affect the quality and continuity of this association. In an environment where women and men are together, the dimension of communication is not the same as places where old and young individuals are together. There is always a situation where men discriminate against women, young people against the elderly, and members of the same religion against other religious groups. This includes gender, race, age, etc. It is a sign that factors significantly affect individual attitudes. From this point of view, this study examines attitudes of college students about elderly discrimination. As the data collection tool "Personal Information Form" consisting of 10 questions and "Elderly Discrimination Attitude Scale (YATÖ)" consisting of 23 questions were used. As a result of the analyses, it was determined that the scores received by the students from the age discrimination attitude scale differ significantly according to the variables such as gender and the program in which they are studying $(\mathrm{p}<0.05)$. As a result, attitudes are at the core of the relationship and communication with individuals. It is therefore important to have positive attitudes and to have a positive outlook for the elderly. From this point of view, it is an important requirement to investigate the attitudes of young university students towards the elderly in planning for the elderly and to provide information that will shed light on the future in the context of eliminating the differences between generations on a social basis.
\end{abstract}

Key Words: Discrimination, Attitude Scale, University Student, Aging, Older People

\section{Atıf İçin / Please Cite As:}

Altun, A. ve Demirel, B. (2020). Üniversite öğrencilerinin yaşlı ayrımcılığıyla ilgili tutumları: Keskin MYO örneği. Manas Sosyal Arastirmalar Dergisi, 9(1), 423-434.

\footnotetext{
1 Öğr. Gör. - Türkiye - Kırıkkale Üniversitesi, Yabancı Diller Yüksekokulu, ati_altun@yahoo.com ORCID: 0000-0002-7860-706X

2 Öğr. Gör. - Türkiye - Kırıkkale Üniversitesi, Delice Meslek Yüksekokulu, bdbarisdemirel@gmail.com ORCID: 0000-0001-5916-4999
} 


\section{Giriş}

Yaşlılık kavramı, dünya nüfusunun giderek yaşlanması ve genç nüfusun genel nüfus içindeki payının azalmasıyla ilişkili olarak ön plana çıkmaktadır. Yaşlılık alanı ile ilgili çalışma yapan akademik disiplinlerin de (Tip, hemşirelik, sosyal hizmet, psikoloji, sosyoloji vb. gibi) bu yönü ile dikkatini çekmektedir. Yaşllık tüm hayati aktivitelerde, üretkenlikte, kendi kendine yetebilirlikte ve bağımsız hareket etmede azalmaların yaşandığ1 bir dönem olarak düşünülmektedir (Şahin ve Erdem, 2017). Yaşllılk ve yaşlanmaya dair birçok tanım bulunmakla birlikte 'Yaşlı, yaşa bağlı olarak fonksiyon kaybı yaşayan ve günlük yaşam aktivitelerini yerine getirme hususunda sorunlarla karşılaşan bireyler olarak tanımlanabilirken yaşlanma da bu sürece verilen ad" olarak ifade edilebilir. Literatürde yer alan diğer bazı yaşlı ve yaşlanma kavramlarına dair açıklamalara aşağıda yer verilmiştir:

Yaşlılık ile ilgili tanımlara bakıldığında yaşlılığın genel olarak 3 temel üzerinde tanımlandığını söyleyebiliriz. Bu temellere bakıldığında; sosyal hizmet disiplininde de olduğu gibi bireyin biyopsikososyal bir varlık olarak değerlendirilmesi gerektiği vurgusu ile bir kez daha karşılaşmaktayız. Yani bireyin biyolojik, sosyal ve psikolojik yönleri ile var olan bir canlı olduğu vurgulanabilir.

Biyolojik yaşlanma, yaş ile bağlantılı olarak bedenin diriliğinin azaldığı, temel fonksiyonlarını yerine getirme dağarcığını kaybettiği ve kaçınılmaz olarak insan yaşamının son bulması ile neticelenen bir süreçtir (Öksüzokyar vd., 2016). Dünya sağlık örgütünün 2018 yllında yayınladı̆̆ "Yaşlanma ve Sağlık" raporu da biyolojik yaşlanmaya dair yukarıda verilen literatür bilgisini desteklemektedir. Bu rapora göre insan, biyolojik olarak zaman içinde çok çeşitli moleküler ve hücresel hasarın birikmesinin etkisinde kalmakta ve bu, fiziksel ve zihinsel kapasitede kademeli bir düşüşe, artan hastalık riskine ve nihayetinde ölüme yol açmaktadır (DSÖ Ageing and Health, 2018).

Psikolojik yaşlanma, bireylerin yaşlilık aşamasında geçirdikleri davranış, uyum ve mental fonksiyonlarındaki değişimleri kapsayan bir süreçtir (Aslan ve Hocaoğlu, 2017). Psikolojik açıdan yaşlanmanın temelinde fonksiyon kaybı olduğunu söylemek yanlış olmayacaktır.

Sosyal Yaşlanma, modası geçme, yaşlanma ve toplumdan uzaklaşma gibi risklerin artmasılyla birlikte bireyin anlamlı sosyal işlevlerden (aile sorumlulukları ve çalışma süreci gibi) vazgeçme sürecini ifade eder (Livi-Bacci, 1982, s. 771). Yaşa bağlı olarak bireylerin sosyal hayat içindeki rol ve sorumluluklarının değişmesi; toplumdaki diğer bireylerin de yaşlanan kimseden sergilemesini beklediği davranışlan içerir. Butler, sosyal yaşlanmayı kuşak çatışması çerçevesinde değerlendirerek yaşlanmayı öznel bir deneyim olarak ele alarak, orta yaşlıların yaşlılara, diğerlerinde gençlere karşı önyargılarını ciddi bir sorun olarak tanımlar. Genç kuşaklar açısından yaşlanmak, hastalanmak ve sakat kalmaya karşı kişisel bir hoşnutsuzluk düşüncesi iken yaşlilar için güçsüzlük, yararsızlık ve ölüm korkusunun ifadesidir (Butler, 1969, s. 243).

Yaşlı tanımlarına bakıldığında ise; genel tanımın ya da sınıflandırmanın kronolojik olarak yapıldığı doğum y1lının esas alındığı 'ömür süresi’ ile ilgili olduğu söylenebilir. Dünya Sağlık Örgütü yaşlılık kavramını sosyal çevreye uyum beceresinde meydana gelen azalma olarak ifade etmektedir (Gökçe Kutsal, 2007). Aynı zaman da yaş alma süreci olarak da canlının doğumundan ölümüne kadar geçen zaman da yaşlanma olarak tanımlanmaktadır (Önal-Dölek, 2011).

Dünya Sağlık Örgütü' nün yaşlılık tanımındaki kronolojik sınıflandırmada ise 65 yaş alt sınır olarak belirtilmektedir. Birleşmiş Milletlere göre ise yaşlılık da alt yaş sınırı 60 yaş olarak belirlenmiştir (www.turkgeriatri.org.tr). Literatürün genelinden çıkarılan sonuca göre kabul edilen asgari yaşlılık yaşının 65 olduğu söylenebilir (Zastrow, 2013). Ülkemizde Aile ve Sosyal Politikalar Bakanlı̆ı (Mülga), Çalısma, Sosyal Hizmetler ve Aile Bakanlığına bağlı Engelli ve Yaşlı Hizmetleri Genel Müdürlüğü mevzuatında yer alan " Huzurevleri ile Huzurevi Yaşlı Bakım ve Rehabilitasyon Merkezleri Yönetmeliği " nde yaşlı tanımına ilişkin olarak asgari yaş sınırı olarak 60 yaş ve üzeri ortaya konulmaktadır (www.eyh.aile.gov.tr). Buradan hareketle yaşlılık dönemine ilişkin kronolojik sınıflandırmada 60 ve 65 yaşlarının asgari sınır olarak ön plana çıktığ ifade edilebilir.

İstatistiksel açıdan yaşllıı ve yaşlanmaya dair temel bilgilere bakıldığında ABD nüfus bürosunun öngörüsüne göre 2020 yılına gelindiğinde her 6 (altı) Amerikalı'dan birisinin yaşlılardan oluşacağı verisine ulaşılabilir (Çakır ve Palabıyıkoğlu, 1997). Türkiye İstatistik Kurumunun 2016 yılı raporu incelendiğinde de ülkemizde ortalama yaşam süresinin 78 yıla ulaştı̆̆ı, 2023 yllına gelindiğinde ise genel nüfus içinde yaşlı nüfus oranının \% 10,2' ye ulaşacağı 2050 yllına gelindiğinde \% 20,8' e ulaşacağı 2075 yllina gelindiğinde ise \% 27,7’ ye ulaşacağ1 öngörüsüne yer verilmektedir (TÜİK). Dünya Sağlık Örgütü, küresel boyutta 
insanların artık daha uzun ömürlerinin olduğu; 60 yaşın üzerindeki birey sayısının 2050 yllına gelindiğinde \% 100 artarak 2 milyar insana ulaşacağı ön görüsünü ortaya koymaktadır (WHO-DSÖ, 2015).

$\mathrm{Bu}$ çalışmanın yapılmasının gerekçesi, dünya genelinde olduğu gibi ülkemizde de yaşlı nüfus oranlarının giderek artması; buna bağlı olarak yaşlıların kendi sorunları ve ihtiyaçlarının yanı sıra toplumun diğer kesimleri tarafından yaşlılara atfedilen anlam ve bakış açısında değişikliğin meydana gelme olasılığıdır. Çalışmanın önemi ise, toplum içinde yaşlılarla birlikte yaşamanın yanı sıra çeşitli kurum ve kuruluşlarda yaşlılarla ilgili alanlarda çalışma hayatına atılacak olan genç üniversitelilerin bakış açılarının belirlenmesi ve muhtemel olumsuzlukların giderilebilmesi noktasında önleyici bir projeksiyon sunmaktır. Bu bağlamda mevcut literatüre de katk1 sağlayacağ1 düşünülmektedir.

\section{Yaşlı Ayrımcıllı̆ 1}

Biyopsikososyal açıdan yaşlanan bireylere ilişkin toplum içinde ötekileştirici tutumların olması, yaşlıların artık toplumdan uzak yaşamaları gerektiğinin düşünülmesi, yaşlıların değer ve tutumlarına sayg1 duyulmaması ise yaşlı ayrımcıllŏı olarak nitelenebilir. Ayrımcılık kavramı olumsuzluk çağrıştıran bir kavram olmasının yanı sıra yaşlılara yönelik pozitif ayrımcllı̆ı kapsadığını da unutmamak gerekir. Bilgelik, saygınlık ve güvenilirlik gibi özellikler de yaşlılara atfedilen özellikler ya da ayrımcllık konusunda başta gelen başlıklardır.

Yaşlı ayrımcılığı kavramı 1969 yllında ABD Ulusal Yaşlılık Enstitüsü başkanı R. Butler tarafından kullanılmış ve literatüre kazandırılmıştır. Gerontoloji uzmanı olan Butler, yaşılıara yönelik cinsiyet ve ırk ayrımcılığı gibi bir ayrımcılıklar olarak yaşlı ayrımcılı̆̆ını tanımlamıştır (Butler, 1969). Yaşlı bireylerin biyopsikososyal açıdan gerilemesi ve kronolojik olarak yaşlanmasından dolayı maruz kaldıkları ayrımcıllğa da yaşlı ayrımcilığı denilebilir. Nitekim Vefikuluçay'a (2008) göre de bir bireye sadece yaşı nedeniyle gösterilen tavır, önyarg1, davranış ve eylemlerde diğer bireylere göre farklı tutum ve davranış geliştirme yaşlı ayrımcıllğı olarak nitelendirilmektedir.

Yaşlı ayrımcilığı konusunda ekonomik, sosyal ve kültürel yapıların etkili olduğu ifade edilebilir. Bu doğrultuda normal hayat süreçlerinden zorunlu olarak kopartılan yaşlıların kendi hayat tarzlarından uzaklaştırılması, onların genç kuşaklar tarafından alaya alınması, güçsüzlüklerinin kullanılması ve yetersizliklerinden dolayı dikkate alınmamaları bu eşitsizliğin ve ayrımcllğın ortaya çıkmasında önemli etkenlerdendir (Butler, 1969, s. 244). Ayrıca sosyal, kültürel ve ekonomik bağlamlarda yaşanan dişlanmalar, yaşılıarın çeşitli şekillerde sosyal hayata katılımını sınırlandırabilir (Zakowicz, 2012, s. 45):

- Sosyal ve kültürel açıdan önemli roller üstlenmelerini sağlayacak yeterli araçların bulunmaması,

- Kültürel basmakalıp ve önyargilarla dayatılan ayrımcilık objeleri olmak,

- Sosyal kaynaklardan pay alma yeteneklerini sinırlayan özelliklere sahip olma

- Yaşl1lı̆̆1 yaşamın bir aşaması olarak tanımlayan bireysel özelliklerin varllğı gibi durumlar ayrımcıllğın ortaya çıkmasında etkili olduğu söylenebilir.

Bir başka deyişle yaşlı ayrımcılloğ olgusunun ortaya çıkmasında yaşlılara karşı uygunsuz davranışlar, haksız kültürel klişelerin varllğı, önyargıların varllğı veya yaşlılardan korkma, yaşlılık hakkında güvenilir bilgi eksikliği, yaşlılık ile hastalık ve ölüm arasındaki ilişki ve yaşlıların hem aile hem de toplumdaki statüsünün değişmesi gibi durumlar temel oluşturmaktadır. Yaşlılara yönelik yukarıda sıralanan olumsuz yaklaşım ve bakış açılarına ek olarak yaşıı bireyin kadın olması, yoksul olması ya da azınlık olarak nitelenen bir etnik kimliğe sahip olması da onları daha dezavantajlı bir noktaya taşımaktadır (Buz, 2015).

Yaşlı nüfusunun ülkemizde de giderek artış göstermesi göz önünde bulundurulduğunda yaşlıllk alanında çalışacak bireylerin artırılması ve üniversite öğrencilerinin yaşlı ayrımcılığı tutumlarının değerlendirilerek daha makro boyutta çalışmaların yapılabilmesi sağlanmalıdır (Özkan ve Bayoğlu, 2011). Yaşlı yetişkinlerin oranı nüfus içinde arttıkça, gençlerin karşı tutumların belirleyicilerini anlamak önemli görülmekte ve böylece yaşlılara karşı daha olumlu tutumları teşvik etmek mümkün olabilir (Allan ve James, 2009). Bu araştırmada bu bağlamda şekillendirilmiş olup üniversite öğrencilerinin yaşlı ayrımcllğıyla ilgili tutumlarının belirlenmesi üzerine odaklanılmıştır. 


\section{Yöntem}

Bu araştırma, Kırıkkale Üniversitesi Keskin Meslek Yüksekokulu öğrencilerinin yaşlı ayrımcıllı̆ıyla ilgili tutumlarını belirlemek amacıyla yapılmışır.

\section{Evren - Örneklem}

Araştırmanın evrenini 2017-2018 eğitim-öğretim yllında Keskin Meslek Yüksekokulunda kaydı bulunan öğrenciler oluşturmuştur. Araştırmada evrenin tamamının alınması hedeflenmiş bu nedenle örneklem seçimi yapılmamıştır. Ancak, uzun süredir okulda kaydı bulunmasına rağmen aktif olarak eğitimine devam etmeyen öğrencilerin bulunması, bazı programların öğrenci alımını durdurması gibi nedenlerle mevcut durumda okula devam eden öğrenci sayısının oldukça düşük olduğu tespit edilmiştir.

Araştırmada bireylerin toplumsal davranışlarını, yaşlı ayrımcıllğına yönelik eğilimlerini gözlem ve test yoluyla objektif bir biçimde ölçmek ve bu durumu sayısal verilerle ortaya koymak hedeflenmiştir. $\mathrm{Bu}$ bağlamda nicel araştırma yönteminde araştırılan konuya dair evrenin temsili dikkate alınarak çalışma grubunun azami sayısına ulaşılması planlanmıştır. Bu nedenle veri toplama süreci 322 öğrenci ile yürütülmüştür. Nicel araştırma modellerinden de belli bir değişken açısından (cinsiyet, yaş, öğrenim gördüğü bölüm...) farklılaşan grupları birbirleriyle kıyaslayan nedensel-karşılaştırma modelinden yararlanılmıştır.

\section{Veri Toplama Araçları}

Araştırma verileri 01.11.2017- 01.01.2018 tarihleri arasında toplanmıştır. Veri toplama aracı olarak araştırmacılar tarafindan literatür taraması sonrasında 10 sorudan oluşan kişisel bilgi formu ve 23 sorudan oluşan "Yaşlı Ayrımcllı̆̆ Tutum Ölçeği (YATÖ)" kullanılmıştır. Veriler yüz yüze görüşme yolu ile toplanmıştır. Nicel araştırma deseninin doğasına uygun olarak araştırma sonuçlarında ilişki ve farklar gibi istatistiksel sonuçlar aranmıştır.

Yaşl Ayrmmcllŭğ Tutum Ölçeğ̊: YATÖ yaşlının yaşamını sınırlama, yaşlıya yönelik olumlu ayrımcllık ve yaşlıya yönelik olumsuz ayrımcılık konularını içeren üç alt boyutu bulunmaktadır. Bu ölçek Vefikuluçay tarafından 2008 yılında geliştirilmiştir. Ölçeğin geçerlilik-güvenirlilik çalışması yapılarak, Cronbach Alfa güvenirlik katsayısı 0.80 bulunmuştur. Yaşllara yönelik ifadelerin bulunduğu her madde için "Kesinlikle Katılmıyorum", "Katılmiyorum", "Kararsızım", "Katıllyorum" ve "Kesinlikle Katillyorum" cevaplarının bulunduğu 5'li Likert tipi bir ölçek kullanılmıştır. Ölçek, olumlu veya olumsuz tutum ifadelerini kapsamaktadır.

Yaşlı ayrımcilığ1 ile ilgili olarak olumlu tutum cümleleri: kesinlikle katıllyorsa “5”, katıllyorsa "4", kararsızsa "3", katılmıyorsa " 2 " ve kesinlikle katılmıyorsa " 1 " puan olarak değerlendirmeye alınmaktadır. Yine aynı ölçekteki olumsuz tutum cümleleri ise: kesinlikle katilıyorsa "1", katıllyorsa "2", kararsızsa "3", katılmıyorsa "4" ve kesinlikle katılmıyorsa "5" puan olacak şekilde değerlendirmeye alınmaktadır. Ölçekten alınan puanın yüksekliği, yaşlı ayrımcilığıla ilgili olumlu tutumların da yüksek olduğu anlamına gelmektedir. Bu bağlamda ölçekten alınabilecek en yüksek puan 115 iken en düşük puan ise 23 'tür.

Tutum ölçeği üç alt boyuttan meydana gelmektedir. İlk alt boyut "Yaşlınn Yaşamm Sinırlama" alt boyutudur ve bu boyut toplumun, yaşlının sosyal yaşamını sınırlamaya ilişkin inanç ve algılarını ölçmektedir. Yaşlının yaşamını sınırlama alt boyutundan alınabilecek en yüksek puan 45 iken en düşük puan ise 9'dur. "Yaşllya Yönelike Olumlu Ayrmmcllke" alt boyutu bir diğer alt boyut olup, toplumun yaşliya yönelik olumlu inanç ve algılarını ölçmektedir. Yaşlıya yönelik olumlu ayrımcılık alt boyutundan alınabilecek en yüksek puan 40 en düşük puan ise 8'dir. Üçüncü alt boyut ise "Yasshya Yönelik Olumsuz Ayrmmchlke" alt boyutudur ve toplumun yaşlı bireye yönelik olumsuz inanç ve algilarını ölçmektedir. Yaşlıya yönelik olumsuz ayrımcllık alt boyutundan alınabilecek en yüksek puan 30 iken en düşük puan ise 6'dır (Vefikuluçay ve Terzioğlu, 2011). Veriler ders saatlerine engel olmadan, sınıf ortamında toplanmıştır. Araştırma ile ilgili gerekli bilgilendirmeler yapıldıktan sonra, bütün öğrencilerden gönüllülük esasına dayalı olarak çalışmaya katılım onamları alınmış ve yaklaşık 15 dakika süren anket formunu doldurmaları istenmiştir.

\section{Verilerin Analizi}

Yapılan çalışma neticesinde elde edilen verilerin değerlendirilmesi için "Statistical Package for the Social Sciences (SPSS) 18.0" istatistik analiz programı kullanılmıştır. Değerlendirmede katılımcılara dair tanıtıcı bulgular niteliğinde frekans, yüzde dağlımlarına yer verilmiş ve tablo halinde bulgular içerisinde 
sunulmuştur. Ayrıca istatistiksel olarak yapılan normallik dağılımı analizine bağlı olarak elde edilen verilerin normal dağılım gösterdiği belirlenmiştir $(\mathrm{p}<0.05)$. Normal dağılım göstermesinin sonucuna bağlı olarak da t-testi ve tek yönlü ANOVA istatistiksel analiz yöntemlerinden yararlanılmıştır. Analiz sonrasında elde edilen bulgulara aşağıda yer verilmiştir.

\section{Bulgular}

Araştırmanın amaçları doğrultusunda, anket formları SPSS programına özenle girildikten sonra verilerin istatistiksel analizi yapılmışır. Bulgular aşağıda sunulmuştur.

Tablo 1. Öğrencilerin Sosyo-Demografik Özellikleriyle İlgili Bilgiler

\begin{tabular}{|c|c|c|c|}
\hline Demografik Özellikler & & $N$ & $\%$ \\
\hline \multirow{2}{*}{ Cinsiyet } & Kadin & 243 & 75.5 \\
\hline & Erkek & 79 & 24.5 \\
\hline \multirow{4}{*}{ Yaş } & $18-20$ & 243 & 75.5 \\
\hline & $21-23$ & 59 & 18.3 \\
\hline & $24-27$ & 13 & 4.1 \\
\hline & $28+$ & 7 & 2.2 \\
\hline \multirow{6}{*}{ Öğretim Programı } & Muhasebe ve Vergi Uygulamaları & 10 & 3.1 \\
\hline & Çocuk Gelişimi & 170 & 52.8 \\
\hline & Yerel Yönetimler & 63 & 19.6 \\
\hline & Halkla İlişkiler ve Tanıtım & 58 & 18.0 \\
\hline & Pazarlama & 9 & 2.8 \\
\hline & İnsan Kaynakları Yönetimi & 12 & 3.7 \\
\hline \multirow{2}{*}{ Eğitime Devam Ettiği Sınıf } & 1. Sinif & 171 & 53.1 \\
\hline & 2. Sinif & 151 & 46.9 \\
\hline \multirow{2}{*}{$\begin{array}{l}\text { Okuduğu Programı İsteyerek Tercih } \\
\text { Etme Durumu }\end{array}$} & Evet (İsteyerek Tercih) & 278 & 86.3 \\
\hline & Hayır (İstemeyerek Tercih) & 44 & 13.7 \\
\hline \multirow{4}{*}{ Barınma Durumu } & Aile Yanında & 65 & 20.2 \\
\hline & Apart, Yurt, Kişisel Ev vb. & 243 & 75.5 \\
\hline & Akraba Yanında & 11 & 3.4 \\
\hline & Diğer & 3 & 0.9 \\
\hline \multirow{5}{*}{ En İyi Anlaşılan Aile Üyesi } & Büyükanne-Büyükbaba & 4 & 1.2 \\
\hline & Anne-Baba & 203 & 63.1 \\
\hline & Kardeş & 59 & 18.3 \\
\hline & Hepsi & 28 & 8.7 \\
\hline & Hiçbiri & 4 & 1.2 \\
\hline \multirow{5}{*}{$\begin{array}{l}\text { Yaşlı Bireyin Nerde Kalmasına Dair } \\
\text { Görüş }\end{array}$} & Yaşlı Kendi Evinde Kalmalı & 139 & 43.2 \\
\hline & Yaşlı Çocuklarının Yanında Kalmalı & 172 & 53.4 \\
\hline & Huzurevi vb. Kuruluşlarda Kalmalı & 5 & 1.6 \\
\hline & Hiçbiri & 6 & 1.9 \\
\hline & Toplam & 322 & 100.0 \\
\hline
\end{tabular}

Tablo 1'de verilen bulgular ışığında; çalışmaya katılan öğrencilerin \% 75,5’inin kadın ve \% 24,5'inin erkek olduğu, \% 75,5'inin ise 18-20 yaş aralığında oldukları belirlenmiştir. Araştırmaya katılan öğrencilerin \% 52,8’i Çocuk Gelişimi programında öğrenim görmekte iken en az katılımcının ise \% 3,1 ile Muhasebe ve Vergi Uygulamaları programında öğrenim gördüğü tespit edilmiştir. Bu yüzdeler arasındaki farkın bölümlere kayıt oranlarıyla paralellik gösterdiği söylenebilir (Çocuk Gelişimi programı Keskin Meslek Yüksekokulu'nda en çok kayıt yapılan program iken Muhasebe gibi bazı programlarda ise kontenjanlar tam olarak doldurulamamaktadır). Katılımcıların \% 46,9’luk kesimi 2. sınıf öğrencisi olarak eğitimine devam ederken; \% 86,3'ünün de okuduğu programı isteyerek tercih ettiği ve öğrenim gördüğü bulgusuna ulaşılmıştır.

Yine Tablo 1'e göre katılımcıların \% 87,9'u yapı olarak çekirdek aile yapısına mensup oldukları belirlenmiş, yine katılımcıların \% 75,5’inin apart, yurt ve kişisel evlerinde barındıklarını ifade etmişlerdir. Bu durum yüksekokul öğrencilerinin çoğunlukla şehir dışından geldiğini de işaret etmektedir. Katılımcıların $\% 63,1$ 'i en iyi anlaştıkları aile üyesi olarak anne ve babalarını ifade ederken en az anlaştıkları aile üyesinin büyükanne ve büyükbabaları $(\% 1,2)$ olduğunu ifade etmişlerdir. $\% 53,4$ 'lük katılımcı grubu yaşlıların çocuklarının yanında kalması gerektiğini beyan ederken, \% 43,2'si ise yaşlıların kendi evlerinde kalmaları gerektiğini belirtmiştir. 
Tablo 2. Öğrencilerin Yaşlı Ayrmoılı̆̆ Tutumlarna İlişkin Genel Puanları ve Alt Boyutlarndan Aldıklar Puanlarn Dă̆lımı

\begin{tabular}{|c|c|c|c|c|c|}
\hline Değer & $\begin{array}{c}\text { Yaş1 } \\
\text { Aytımcilŭ̆ }\end{array}$ & $\begin{array}{c}\text { Yasamini Sinirlama Alt } \\
\text { Boyutu }\end{array}$ & $\begin{array}{c}\text { Olumlu Aytimcilik Alt } \\
\text { Boyutu }\end{array}$ & $\begin{array}{c}\text { Olumsuz Aytimcilhk } \\
\text { Alt Boyutu }\end{array}$ & $N$ \\
\hline En Düşük & 34.0 & 11.0 & 8.0 & 8.0 & \multirow{4}{*}{322} \\
\hline En Yüksek & 93.0 & 34.0 & 40.0 & 29.0 & \\
\hline Ortalama & 69.57 & 19.55 & 30.83 & 19.19 & \\
\hline Std. Sapma & 8.27 & 3.92 & 5.12 & 3.61 & \\
\hline
\end{tabular}

Tablo 2’de Yaşlı Ayrımcılığı Tutum Ölçeği (YATÖ) puanları üzerinden gerçekleştirilen analize göre katılımcıların ölçekten aldıkları en düşük puanın 34, en yüksek puanın ise 93 olduğu görülmüştür. Ortalama puan $69.57 \pm 8.27$ şeklinde bulunmuştur. Ölçekten alınacak puanların en düşük 23 ve en yüksek 115 olduğu ve puan arttıkça olumlu tutumun arttığ1 göz önünde bulundurulduğunda, katılımcıların ortalama bir değere sahip oldukları, nispeten yaşlı ayrımcılığın karşı olumlu tutum sergiledikleri ifade edilebilir.

Yaşamını sınırlama alt boyutu ortalama puanı $19.55 \pm 3.92$ olarak belirlenmiştir. Bu alt boyuttan alınacak puan ortalamasının en yüksek puan olan 45'in yarısına yakın bir değer olması öğrencilerin yaşlının yaşamını sınırlama boyutuyla ilgili olarak kararsız kaldıklarını göstermekte iken, puan ortalamasının 9'a yakın olması, yaşlının yaşamını sınırlama boyutuna ilişkin öğrencilerin tutumunun olumsuz olduğunu ortaya koymaktadır. Buna göre yaşamını sınırlama alt boyutu ortalama puanının 9'a daha yakın olduğu ve öğrencilerin yaşlıların yaşamını sınırlama konusunda olumsuz tutuma sahip olduklarının belirlendiği söylenebilir.

Olumlu ayrımcılık alt boyutu ortalama puanı $30.83 \pm 5.12$ olarak bulunmuştur. Bu alt boyuttan alınacak en yüksek puan ortalaması 40 iken araştırmamızın da bu değere yakın olması öğrencilerin yaşlıya yönelik olumlu ayrımcılık boyutuna ilişkin tutumunun olumlu olduğunu göstermekte iken puan ortalamasının 8'e yakın olması yaşlıya yönelik olumlu ayrımcılık boyutuna ilişkin öğrencilerin tutumunun olumsuz olduğunu göstermektedir. Buna göre yaşlıya yönelik olumlu ayrımcılık alt boyutu ortalama puanının 40’a daha yakın olduğu ve öğrencilerin yaşlılara yönelik olumlu ayrımcılık sağlanması konusunda olumlu tutuma sahip oldukları belirlenmiştir.

Olumsuz ayrımcilık alt boyutu ortalama puanı $19.19 \pm 3.61$ olarak bulunmuştur. Bu alt boyuttan alınacak en yüksek puan ortalaması olan 30'a yakın olması öğrencilerin yaşlıya yönelik olumsuz ayrımcılık boyutuyla ilgili tutumunun olumlu olduğunu göstermekte iken puan ortalamasının 6'ya yakın olması yaşliya yönelik olumsuz ayrımcıllk boyutuyla ilgili öğrencilerin tutumunun olumsuz olduğunu göstermektedir. Buna göre yaşlıya yönelik olumsuz ayrımcılık alt boyutu ortalama puanının 30'a daha yakın olduğu ve ögrencilerin yaşlılara yönelik olumsuz ayrımcılık sağlanması konusunda olumlu tutuma sahip oldukları verisine ulaşılmıştır.

Tablo 3. Öğrencilerin Yaşl Ayrmaılı̆g Tutum Değerlerinin Cinsiyet Değiskeenine Göre İliskeisiz Örneklemler t-testi Analizi Sonuclar

\begin{tabular}{|c|c|c|c|c|c|c|}
\hline Yaşlı Aytımcıliğı Tutumlant & Cinsiyet & $N$ & Ortalama & $S d$ & $T$ & $P$ \\
\hline \multirow{2}{*}{ Yaşlı Ayrımcılığ1 } & Kadin & 243 & 68.74 & \multirow{2}{*}{1.06} & \multirow{2}{*}{3.20} & \multirow{2}{*}{$0.001 *$} \\
\hline & Erkek & 79 & 72.13 & & & \\
\hline \multirow{2}{*}{ Yaşamını Sınırlama Alt Boyutu } & Kadin & 243 & 20.47 & \multirow{2}{*}{0.50} & \multirow{2}{*}{2.41} & \multirow{2}{*}{$0.016^{*}$} \\
\hline & Erkek & 79 & 19.25 & & & \\
\hline \multirow{2}{*}{ Olumlu Ayrımcılık Alt Boyutu } & Kadin & 243 & 19.81 & \multirow{2}{*}{0.47} & \multirow{2}{*}{1.75} & \multirow{2}{*}{0.081} \\
\hline & Erkek & 79 & 30.50 & & & \\
\hline \multirow{2}{*}{ Olumsuz Ayrimcilık Alt Boyutu } & Kadin & 243 & 19.81 & \multirow{2}{*}{0.47} & \multirow{2}{*}{1.75} & \multirow{2}{*}{0.081} \\
\hline & Erkek & 79 & 18.99 & & & \\
\hline
\end{tabular}

Araştırmaya katılan Keskin MYO Öğrencilerinin yaşlı ayrımcılı̆̆1 tutum ölçeğinden aldı̆̆1 puanlar cinsiyet değişkenine göre anlamlı bir farklılık göstermektedir $(p<0.05)$. Erkek ve kız öğrencilerin ölçekten aldığı ortalama puanlar karşılaştırıldığında erkeklerin (72.13 \pm 1.06$)$ yaşlı ayrımcılığına daha olumlu baktıkları ifade edilebilir.

Yaşamını sınırlama alt boyutunda da cinsiyete göre anlamlı farklılık olduğu belirlenmiştir $(\mathrm{p}<0.05)$. Erkek ve kız öğrencilerin ölçeğin alt boyutundan aldığ1 ortalama puanlar karşılaştırıldığında erkeklerin (19.25 土 0.50) yaşlı yaşamını sınırlamaya yönelik daha olumsuz bir bakış ortaya koydukları ifade edilebilir. 
Olumlu ayrımcllık ve olumsuz ayrımcllık alt boyutlarına göre cinsiyet açısından istatistiksel anlamlı bir fark bulunamamıştır ( $\mathrm{p}>0.05)$.

Tablo 4. Ögrencilerin Yaşl Ayrmolly̆g Tutum Puanlarmm Yaş Değģşkenine Göre Tek Yönlü ANOV A Analizi Sonuclar

\begin{tabular}{|c|c|c|c|c|c|}
\hline Yashli Aytımc1lĭ̆ı Tutumlatı & Yas & $N$ & Ortalama & $F$ & $P$ \\
\hline \multirow{4}{*}{ Yaşlı Ayrımcılığ1 } & $18-20$ & 243 & 69.80 & \multirow{4}{*}{0.842} & \multirow{4}{*}{0.588} \\
\hline & $21-23$ & 59 & 69.20 & & \\
\hline & $24-27$ & 13 & 69.11 & & \\
\hline & $28+$ & 7 & 65.86 & & \\
\hline \multirow{4}{*}{ Yaşamını Sınırlama Alt Boyutu } & $18-20$ & 243 & 19.43 & \multirow{4}{*}{1.221} & \multirow{4}{*}{0.276} \\
\hline & $21-23$ & 59 & 19.63 & & \\
\hline & $24-27$ & 13 & 17.74 & & \\
\hline & $28+$ & 7 & 21.43 & & \\
\hline \multirow{4}{*}{ Olumlu Ayrimcilik Alt Boyutu } & $18-20$ & 243 & 30.99 & \multirow{4}{*}{1.259} & \multirow{4}{*}{0.253} \\
\hline & $21-23$ & 59 & 30.42 & & \\
\hline & $24-27$ & 13 & 31.39 & & \\
\hline & $28+$ & 7 & 27.57 & & \\
\hline \multirow{4}{*}{ Olumsuz Ayrımcilık Alt Boyutu } & $18-20$ & 243 & 19.38 & \multirow{4}{*}{1.755} & \multirow{4}{*}{0.068} \\
\hline & $21-23$ & 59 & 17.21 & & \\
\hline & $24-27$ & 13 & 19.98 & & \\
\hline & $28+$ & 7 & 16.86 & & \\
\hline
\end{tabular}

Araștırmava katılan Keskin MYO Öğrencilerinin yaşlı ayrımcllı̆̆1 tutum ölçeğinden ve alt boyutlarından aldığı puanlara bakıldığında yaş değişkenine göre istatistiksel açıdan anlamlı bir farklılık olmadığı belirlenmiştir ( $\mathrm{p}>0.05)$.

Tablo 5. Ögrrencilerin Yaşh Ayrmmclĭğ Tutum Puanlarmm Öğrencisi Olduklar Program Değğskenine Göre Tek Yönlü ANOV A Analizi Sonuclar

\begin{tabular}{|c|c|c|c|c|c|}
\hline Yaşl Aynımcıliğı Tutumlant & Öğretim Programı & $N$ & Ortalama & $F$ & $P$ \\
\hline \multirow{6}{*}{ Yaşlı Ayrımcılı̆̆ı } & Muhasebe ve Vergi Uygulamaları & 10 & 72.58 & \multirow{6}{*}{3.278} & \multirow{6}{*}{$0.007 *$} \\
\hline & Çocuk Gelişimi & 170 & 67.91 & & \\
\hline & Yerel Yönetimler & 63 & 71.34 & & \\
\hline & Halkla İlişkiler ve Tanıtım & 58 & 71.80 & & \\
\hline & Pazarlama & 9 & 68.74 & & \\
\hline & İnsan Kaynakları Yönetimi & 12 & 71.24 & & \\
\hline \multirow{6}{*}{$\begin{array}{l}\text { Yaşamını Sinırlama Alt } \\
\text { Boyutu }\end{array}$} & Muhasebe ve Vergi Uygulamaları & 10 & 19.10 & \multirow{6}{*}{2.76} & \multirow{6}{*}{$0.019 *$} \\
\hline & Çocuk Gelişimi & 170 & 18.86 & & \\
\hline & Yerel Yönetimler & 63 & 20.66 & & \\
\hline & Halkla İlişkiler ve Tanıtım & 58 & 20.44 & & \\
\hline & Pazarlama & 9 & 19.67 & & \\
\hline & İnsan Kaynakları Yönetimi & 12 & 19.40 & & \\
\hline \multirow{6}{*}{$\begin{array}{l}\text { Olumlu Ayrimcilik Alt } \\
\text { Boyutu }\end{array}$} & Muhasebe ve Vergi Uygulamaları & 10 & 33.30 & \multirow{6}{*}{1.402} & \multirow{6}{*}{0.223} \\
\hline & Çocuk Gelişimi & 170 & 30.44 & & \\
\hline & Yerel Yönetimler & 63 & 30.91 & & \\
\hline & Halkla İlişkiler ve Tanıtım & 58 & 31.32 & & \\
\hline & Pazarlama & 9 & 28.89 & & \\
\hline & İnsan Kaynakları Yönetimi & 12 & 32.83 & & \\
\hline \multirow{6}{*}{$\begin{array}{l}\text { Olumsuz Ayrimcilik Alt } \\
\text { Boyutu }\end{array}$} & Muhasebe ve Vergi Uygulamaları & 10 & 20.18 & \multirow{6}{*}{2.155} & \multirow{6}{*}{0.059} \\
\hline & Çocuk Gelişimi & 170 & 18.60 & & \\
\hline & Yerel Yönetimler & 63 & 19.77 & & \\
\hline & Halkla İlişkiler ve Tanıtım & 58 & 20.02 & & \\
\hline & Pazarlama & 9 & 20.18 & & \\
\hline & İnsan Kaynakları Yönetimi & 12 & 19.00 & & \\
\hline
\end{tabular}

${ }^{* \mathrm{p}}<0.05$

Araştırmaya katılan Keskin MYO Öğrencilerinin yaşlı ayrımcılığı tutum ölçeğinden aldığı puanlar öğrencisi olunan program değişkenine göre anlamlı farkll1ık göstermektedir $(p<0.05)$. Öğrencisi olunan programa göre ölçekten alınan ortalama puanlar karşılaştırıldığında Muhasebe ve Vergi Uygulamaları programında öğrenci olanların yaşlı ayrımcılı̆̆ına daha olumlu baktıkları ifade edilebilir. 
Yaşamını sınırlama alt boyutunda da öğrencisi olunan programa göre anlamlı farklılık olduğu belirlenmiştir $(\mathrm{p}<0.05)$. Tüm öğrencilerin ölçeğin alt boyutundan aldığı ortalama puanlar karşılaştırıldığında Çocuk Gelişimi programında öğrenci olanların yaşlı yaşamını sınırlamaya yönelik daha olumsuz bir bakış ortaya koydukları ifade edilebilir. Olumlu ayrımcılık ve olumsuz ayrımcıllk alt boyutlarına göre öğrencisi olunan program açısından istatistiksel anlamlı bir fark bulunamamıştır ( $\mathrm{p}>0.05)$.

Tablo 6'da verilen değerlere göre, araştırmaya katılan Keskin MYO öğrencilerinin yaşlı ayrımcıllı̆̆1 tutum ölçeği ve alt boyutlarından aldığ1 puanlar mensup olunan aile yapısı değişkenine göre istatistiksel olarak anlamlı farklılık göstermemektedir ( $\mathrm{p}>0.05)$.

Tablo 6. Öğrencilerin Yaşl Ayrmmalı̆̆ Tutum Puanlarmın Mensup Olduğu Aile Yapısı Değiş̧eenine Göre İlişkisiz. Örneklemler t-testi Analizi Sonuclar

\begin{tabular}{|c|c|c|c|c|c|c|}
\hline Yaşh Aytımcıliğı Tutumlant & Aile Yap1s1 & $\bar{N}$ & Ortalama & $S d$ & $T$ & $P$ \\
\hline Yaşlı Ayrımcllığ1 & $\begin{array}{l}\text { Çekirdek Aile } \\
\text { Geniş Aile }\end{array}$ & $\begin{array}{c}280 \\
37\end{array}$ & $\begin{array}{l}69.60 \\
69.03\end{array}$ & 1.46 & 0.396 & 0.693 \\
\hline Yaşamını Sınırlama Alt Boyutu & $\begin{array}{l}\text { Çekirdek Aile } \\
\text { Geniş Aile }\end{array}$ & $\begin{array}{c}280 \\
37\end{array}$ & $\begin{array}{l}19.50 \\
19.93 \\
\end{array}$ & 0.69 & -0.623 & 0.534 \\
\hline Olumlu Ayrımcilık Alt Boyutu & $\begin{array}{l}\text { Çekirdek Aile } \\
\text { Geniş Aile }\end{array}$ & $\begin{array}{c}280 \\
37\end{array}$ & $\begin{array}{l}30.85 \\
30.31\end{array}$ & 1.12 & 0.484 & 0.631 \\
\hline Olumsuz Ayrımcilık Alt Boyutu & $\begin{array}{l}\text { Çekirdek Aile } \\
\text { Geniş Aile }\end{array}$ & $\begin{array}{c}280 \\
37\end{array}$ & $\begin{array}{l}19.25 \\
18.80\end{array}$ & 0.64 & 0.728 & 0.467 \\
\hline
\end{tabular}

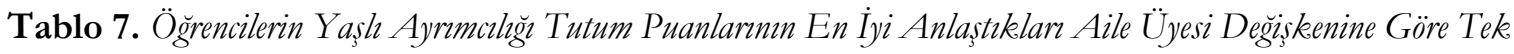
Yönlü ANOV A Analizi Sonuclar

\begin{tabular}{|c|c|c|c|c|c|}
\hline Yaşli Aytımc1liğ1 Tutumlant & En Iyi Anlaşılan Aile Üyesi & $N$ & Ortalama & $F$ & $P$ \\
\hline \multirow{5}{*}{ Yaşlı Ayrımcılığı } & Büyükanne-Büyükbaba & 4 & 65.75 & \multirow{5}{*}{1.686} & \multirow{5}{*}{0.083} \\
\hline & Anne-Baba & 203 & 69.50 & & \\
\hline & Kardeş & 59 & 69.58 & & \\
\hline & Hepsi & 28 & 71.56 & & \\
\hline & Hiçbiri & 4 & 63.75 & & \\
\hline \multirow{5}{*}{ Yaşamını Sinırlama Alt Boyutu } & Büyükanne-Büyükbaba & 4 & 18.50 & \multirow{5}{*}{1.590} & \multirow{5}{*}{0.108} \\
\hline & Anne-Baba & 203 & 20.28 & & \\
\hline & Kardeş & 59 & 19.56 & & \\
\hline & Hepsi & 28 & 20.32 & & \\
\hline & Hiçbiri & 4 & 19.75 & & \\
\hline \multirow{5}{*}{ Olumlu Ayrimcilik Alt Boyutu } & Büyükanne-Büyükbaba & 4 & 22.88 & \multirow{5}{*}{1.459} & \multirow{5}{*}{0.154} \\
\hline & Anne-Baba & 203 & 32.18 & & \\
\hline & Kardeş & 59 & 30.81 & & \\
\hline & Hepsi & 28 & 31.97 & & \\
\hline & Hiçbiri & 4 & 24.75 & & \\
\hline \multirow{5}{*}{ Olumsuz Ayrimcilık Alt Boyutu } & Büyükanne-Büyükbaba & 4 & 18.75 & \multirow{5}{*}{0.308} & \multirow{5}{*}{0.979} \\
\hline & Anne-Baba & 203 & 20.02 & & \\
\hline & Kardeş & 59 & 19.25 & & \\
\hline & Hepsi & 28 & 19.28 & & \\
\hline & Hiçbiri & 4 & 19.25 & & \\
\hline
\end{tabular}

Araştırmaya katılan Keskin MYO Öğrencilerinin yaşlı ayrımcılığı tutum ölçeği ve alt boyutlarından aldığı puanlar en iyi ilişki kurulan aile üyesi değişkenine göre istatistiksel açından anlamlı farklılık göstermemektedir ( $\mathrm{p}>0.05$ ) (Tablo 7). Benzer durum, yaşlıların nerede kalması gerektiği ile ilgili analizlerde de görülmektedir (Tablo 8). Araştırmaya katılan Keskin MYO Öğrencilerinin yaşlı ayrımc1lı̆̆1 tutum ölçeği ve alt boyutlarından aldığı puanlar yaşlıların nerde kalması gerektiği değişkenine göre istatistiksel açıdan anlamlı farklılık göstermemektedir $(\mathrm{p}>0.05)$. 


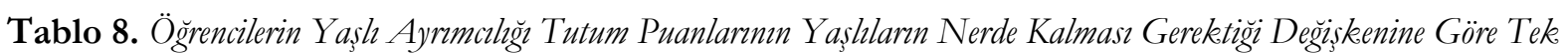
Yönlü ANOV A Analizi Sonuclar

\begin{tabular}{|c|c|c|c|c|c|}
\hline Yashli Aytımc1liğı Tutumlant & Yashlular Nerede Kalmali & $N$ & Ortalama & $F$ & $P$ \\
\hline \multirow{4}{*}{ Yaşlı Ayrımc1lığı } & Yaşlı Kendi Evinde Kalmalı & 139 & 68.95 & \multirow{4}{*}{1.462} & \multirow{4}{*}{0.214} \\
\hline & Yaşlı Çocuklarının Yanında Kalmalı & 172 & 70.29 & & \\
\hline & Huzurevi vb. Kuruluşlarda Kalmalı & 5 & 70.00 & & \\
\hline & Hiçbiri & 6 & 63.13 & & \\
\hline \multirow{4}{*}{ Yaşamını Sinırlama Alt Boyutu } & Yaşlı Kendi Evinde Kalmalı & 139 & 19.40 & \multirow{4}{*}{2.068} & \multirow{4}{*}{0.085} \\
\hline & Yaşlı Çocuklarının Yanında Kalmalı & 172 & 19.73 & & \\
\hline & Huzurevi vb. Kuruluşlarda Kalmalı & 5 & 21.80 & & \\
\hline & Hiçbiri & 6 & 16.00 & & \\
\hline \multirow{4}{*}{ Olumlu Ayrımcılık Alt Boyutu } & Yaşlı Kendi Evinde Kalmalı & 139 & 30.53 & \multirow{4}{*}{0.648} & \multirow{4}{*}{0.629} \\
\hline & Yaşlı Çocuklarının Yanında Kalmalı & 172 & 31.27 & & \\
\hline & Huzurevi vb. Kuruluşlarda Kalmalı & 5 & 31.00 & & \\
\hline & Hiçbiri & 6 & 30.17 & & \\
\hline \multirow{4}{*}{ Olumsuz Ayrımc1lık Alt Boyutu } & Yaşlı Kendi Evinde Kalmalı & 139 & 19.03 & \multirow{4}{*}{1.270} & \multirow{4}{*}{0.282} \\
\hline & Yaşlı Çocuklarının Yanında Kalmalı & 172 & 19.47 & & \\
\hline & Huzurevi vb. Kuruluşlarda Kalmalı & 5 & 17.20 & & \\
\hline & Hiçbiri & 6 & 16.97 & & \\
\hline
\end{tabular}

\section{Tartışma}

Yaşlı nüfusunun ülke genelinde giderek artış göstermesi, yaşlı ayrımcllğına ilişkin bu çalışma ve literatürde daha önce yapılmış benzer çalışmalar için çıkış noktası olmuştur. Bu çalışmada Kırıkkale Üniversitesi Keskin Meslek Yüksekokulu Müdürlüğü bünyesinde yer alan bölüm ve programlarda öğrenim gören öğrencilerin yaşlı ayrımcılığı konusundaki tutumlarını ölçmek hedeflenmiştir. Öğrencilerin yaşlı ayrımcillğı konusunda genel tutumlarının $(69.57 \pm 8.27)$ ortalama bir düzeyde olduğu ve nispeten olumlu bir tutuma sahip oldukları belirlenmiştir. Bu durumu, içinde yaşadığımız toplumun kültürel değerlerinde yaşlının önemli olarak gösterilmesi ile sevilmeyi ve saygıyı hak eden bireyler olduklarının özendirilmesinin doğal bir sonucu olduğunu söylemek mümkündür (Şahin ve Erdem, 2017). Ancak Türk toplum yapisı ve kültürel değerleri göz önünde bulundurulduğunda olumlu tutumun daha yüksek oranda gerçekleşmesinin beklendiği ifade edilebilir. Bu beklenti ve elde edilen sonuç ışığında toplumsal yapi içerisinde yaşlılara atfedilen anlam ve saygınlığın giderek azaldığı söylenebilir.

Literatürde yaşlı ayrımcıllğ̆na ilişkin olarak yapılan yurt içi ve yurt dışı çalışmalara bakııldığında; Ceylan ve Öksüz (2015) tarafindan 418 üniversite öğrencisi, Özkan ve Bayoğlu tarafindan 2011 yllında 278 üniversite öğrencisi, Cheong vd. (2009) tarafından 360 üniversite öğrencisi ve Altay ve Aydın (2014) tarafindan 298 hemşirelik öğrencisi üzerinde yapılan araştırmaların sonucunda yaşı ayrımcıllğına ilişkin öğrencilerin olumlu tutuma sahip oldukları belirlenmiştir. Bu sonuçlar büyük ölçüde bu çalışmanın ana sonucu ile benzerlik göstermektedir. Yine Gallagher vd.'nin 2006 yilında, Liu vd.'nin 2013 yilında hemşireler ve üniversite öğrencileri üzerinde yaptığı yaşlı ayrımcllı̆̆ çalışmasında bireylerin yaşlılara yönelik olumlu tutumlarının oldukları belirlenmiştir. Literatürde yer alan araştırmalarda özellikle hemşirelik bölümü öğrencisi olan üniversitelilerin olumlu tutuma sahip oldukları gözlenmiştir. Bu sonucun hemşirelik ögrencilerinin insanlarla birebir çalışmaları, tedavi ve bakım boyutu ile yaşlıların temel hizmet alan gruplarından olması ile ilişkili olduğu düşünülmektedir. Bu veriler de bu çalışmanın bulguları ile genel olarak benzerlik göstermektedir. Bu çalışmanın yaşlıya yönelik olumlu tutum sonucunun aksine 2015 yılında Köse ve Arkadaşları tarafindan sağlık alanında farklı bölümlerde öğrenim gören 227 üniversite öğrencisi üzerinde yapılan araştırmada ise yaşı ayrımcıllğına ilişkin öğrencilerin olumsuz tutuma sahip oldukları belirlenmiştir. Bu araştırmanın veri toplama sürecinde hem sağlıkçı olup hem askeri öğrenci olanların bulunması sonuçların diğer sağlık bilimleri öğrencilerinin aksine bir şekilde geliştiğini düşündürmektedir.

Yapılan analizler 1şı̆̆ında istatistiksel açıdan anlamlı fark oluşturan sonuçlara bakıldığında öğrencilerin cinsiyetinin ve öğrencisi olunan programın, bireylerin yaşlı ayrımcıllğına ilişkin tutumları üzerinde fark oluşturduğu belirlenmiştir. Erkek öğrencilerin ve Muhasebe ve Vergi Uygulamaları programında öğrenim görenlerin yaşllara karşı daha olumlu bir bakışa sahip olduğu bulgusuna ulaşılmıştır. Ancak öğrencilerin yaşı, mensup oldukları aile türü (çekirdek/geniş aile), en iyi anlaşılan aile üyesi ve yaşlıların nerde kalmasına dair görüşleri gibi değişkenler açısından istatistiksel olarak anlamlı bir farklılık olmadığı tespit edilmiştir. 
Literatürdeki diğer bulgular ile kıyaslandığında cinsiyet açısından birçok çalışmada yaşlıllğa yönelik tutum açısından farklılık olduğu belirlenmiştir. Erdem ve Şahin'in (2017), Hweidi vd.'nin (2006) ve Ceylan ve Öksüz'ün (2015) çalışmasında bu çalışmaya paralel olarak erkek öğrencilerin kız öğrencilere kıyasla daha olumlu tutuma sahip oldukları belirlenmiştir. Bu çalısmanın aksine Ünalan ve arkadaşları (2012) tarafından sağlık personeli üzerinde yapılan çalışmada kadın personelin erkek personele kıyasla; Diego ve arkadaşları (2008) ve Hawkins(1996) tarafindan yapılan çalışmalarda kız öğrencilerin erkek öğrencilere kıyasla yaşlılara yönelik daha olumlu tutuma sahip oldukları belirlenmiştir. Bulgulardaki farklllkkların örneklem grubu farklılıklarından kaynaklanabileceği ve bu çalışmanın büyük çoğunluğunun \% 75,5'lik bir oranla kız öğrencilerden oluştuğu gerekçesi ile olabileceği düşünülmektedir.

Öğrencilerin devam ettiği program açısından Köse ve arkadaşları (2015) tarafindan yapılan çalışmada ögrencisi olunan bölüm veya program açısından anlamlı fark olduğu belirlenmiştir. Yine Diego ve arkadaşları (2008) tarafindan İspanya'da yapılan benzer bir çalışmada öğrencisi olunan bölüm ile yaşıllığa yönelik tutum açısından anlamlı fark olduğu belirlenmiştir. Olumlu bakışın olduğu bölümlerin genel anlamda yaşlı ile çalışma hayatında sıklıkla karşılaşacak olan hemşirelik, tıp ve sosyal hizmet bölümü gibi bölümlerde öğrenci olanlarda olduğu literatür tarafindan desteklenmektedir.

\section{Sonuç ve Öneriler}

Her toplumun kendine özgü gelenek ve kültürlerini koruması, gelecek nesillere ve diğer kültürlere aktarması gerekir. Gerçekten de yaşlı insanlar, gelenekleri, kültürleri ve tarihleriyle derin bir ilişki içinde olan gruptur. $\mathrm{Bu}$ nedenle, toplumun bu grubunun sosyal ve kültürel sermaye birikimine sahip olmas1 önemli bir avantajdır. Her bireyin yaşıı olanlarla devamlı suretle temas halinde olması bu sosyal ve kültürel aktarım için önem arz etmektedir.

Yapılan çalışmada üniversite öğrencilerinin genel olarak yaşlılara karşı olumlu bir tutum sergiledikleri, cinsiyete ve öğrenim görülen bölüme göre anlamlı farkl1lıklar olduğu tespit edilmiştir. Bu durum kuşaklar arası ilişkinin varlığına işaret etmekte ve yaşlılar ve diğer gruplar arasında sosyal, kültürel ve ekonomik ilişskinin devam ettiğini göstermektedir. Bu iletişimin daha iyi sonuçlar doğurması için yaşılıarın modern dünyanın yeniliklerine ve değişimlerine açı, pozitif bakış açılı, kişisel gelişimini sürdüren, merak ve aktivasyonunu kaybetmemiş, yaratıcı problem çözme yeteneğine sahip ve paylaşımcı özelliklere sahip olması gerekir. Diğer taraftan yaşlı ayrımcıllğını en az seviye indirgemek için olumsuz bakış açısından uzak, yaşl1lığın olumlu yanlarını öne süren, önyargılarla mücadele eden, yaşıllığ bir değer olarak gören, onları toplumsal yapıda onurlu bir konumda gören bir kuşak hedeflenmelidir (Zakowicz, 2011, s. 47).

Bütün bu bilgilerden hareketle;

- Üniversite öğrencilerinin yaşlılara yönelik olumlu tutumlarını artırmaya yönelik eğitim müfredatlarının geliştirilmesi ve haricen programlarının hazırlanması,

- Değişen aile yapiları ve toplumsal değişme noktasında gençlerin yaşlı bireylerle daha fazla vakit geçirmelerini sağlayacak aktivitelerin planlanması,

- Yaşlılığın giderek artış gösterdiği ve buna bağlı olarak farkındalık artırıcı kamu spotlarının hazırlanması ve yayginlaştırılması,

- Temel eğitim düzeyinden başlamak üzere yaşlının konumunun anlatılması, bununla ilişkili bir dersin müfredata konularak zorunlu olarak okutulmas1,

- MYO öğrencilerinin yanı sıra tüm üniversite öğrencileri ve toplumun diğer kesimlerinin de yaşlı ayrımcılığına ilişkin tutumlarının belirlemesi amacıyla daha geniş örneklem grupları ile kapsamlı çalışmaların yapilması,

- TÜIKK gibi kurumların ülke genelinde yapacağı daha geniş kapsamlı çalışmalar ile konuya dair ortaya konan olumsuz bulguların gözden geçirilmesi ile sosyal politika üretme ve uygulamasında yol gösterici olması önerilir.

\section{Kaynakça}

Allan, L. J. ve Johnson, J. A. (2009). Undergraduate attitudes toward the elderly: The role of knowledge, contact and aging anxiety. Educational Gerontology, 35, 1-14.

Altay, B. ve Aydın, T. (2015). Hemşirelik öğrencilerinin yaşıı ayrımcllğına ilişkin tutumlarının değerlendirilmesi. Hemsirelikete Eğitim ve Arastırma Dergisi, 12(1), 11-18.

Butler, R. N. (1969). Age-ism: Another form of bigotry. The Gerontologist, 9(4), 243-246. https://doi.org/10.1093/geront/9.4_Part_1.243.

Buz, S. (2015). Yaşlı Bireylere Yönelik Yaş Ayrımcllığı. Elektronik Sosyal Bilimler Dergisi, 14 (53), 268-278. 
Ceylan, H. ve Öksüz, M. (2015). Sosyal hizmet lisans öğrencilerinin yaşlı ayrımcılığına ilişkin tutumlarının incelenmesi. Uluslararast Sosyal Araștırmalar Dergisi, 8(39), 459-466.

Cheong, S. K., Wong, T. Y. ve Koh, G. C. (2009). Attitudes towards the elderly among singapore medical students. Annals Academy of Medicine Singapore, 38(10), 857.

Çakır, Y. ve Palabıyıkoğlu, R. (1997). 12-22 yaş grubundaki gençlerde çok yönlü algılanan sosyal destek ölçeğinin güvenirlik ve geçerlik araştırması. Kriz Dergisi, 5(1),15-25.

Diego, A., Zambrini, B., Moraru, M., Hanna, M., Kalache, A. ve Nunez, J. F. M. (2008). Attitudes toward the elderly among students of health care related studies at the university of salamanca, Spain. Journal of Continuing Education in the Health Professions, 28(2), 86-90.

Dünya Sağlık Örgütü (2015). Yaşlanma Raporu, 2015.

Engelli ve Yaşlı Hizmetleri Genel Müdürlüğ̈ü. http://eyh.aile.gov.tr/mevzuat. (21.07.2018).

Gallagher, S., Bennett, K. M. ve Halford, J. C. (2006). A comparison of acute and long-term health-care personnel's attitudes towards older adults. International Journal of Nursing Practice, 12(5), 273-279.

Gökçe-Kutsal Y. (2007). Yaşlanan dünyanm yaşlanan insanlar (The aging world's aging people). Geriatri Türk Tabipler Birliği Yayınları, Ankara. 13-19.

Michele J. H. (1996). College students' attritudes toward elderly persons. Educational Gerontology, 22(3), 271-279. doi: $10.1080 / 0360127960220305$

Hweidi, I. M. ve Al-Obeisat, S. M. (2006). Jordanian nursing students' attitudes towards the elderly. Nurse Education Today, 26(1), 23-30.

Köse, G., Ayhan, H., Taştan, S., İyigün, E., Hatipoğlu, S. ve Açıel, C. H. (2015). Sağlık alanında farklı bölümlerde öğrenim gören öğrencilerin yaşlı ayrımcılığına ilişkin tutumlarının belirlenmesi. Gülhane Tip Dergisi, 57, 145-151.

Liu, Y., Norman, I. J. ve While, A. E. (2013). Nurses' Attitudes Towards Older People: A Systematic Review. International Journal of Nursing Studies. Doi:/10.1016/j.1jnurstu.2012.11.021.

Livi-Bacci, M. (1982). Social and biological aging: Contradictions of development. Population and Development Review, $8(4), 771-781$.

Öksüzokyar, M. M., Eryiğit, S. Ç., Öğüt-Düzen, K., Erdoğmuş-Mergen B., Sökmen Ü. N. ve Öğüt S. (2016). Biyolojik yaşlanma nedenleri ve etkileri. MAKÜ Sağhk Bilimleri Enstitüsü Dergisi, 4(1), 34-41.

Önal-Dölek, B. (2011). Türkiye'de üniversite hastanelerindeki geriatri bilim dallarna bağl geriatri ünitelerinde verilen bizmetin sosyal hiz̨met temelinde değerlendirilmesi (Doktora Tezi). Hacettepe Üniversitesi, Sosyal Bilimler Enstitüsü, Ankara.

Özkan, Y. ve Bayoğlu, A. S. (2011). Ageism: College students' perceptions about older people. e-Journal of New World Sciences Academy, 6(1), 107-115.

Şahin, H. ve Erdem, Y. (2017). Hemşirelik öğrencilerinin yaşlılara yönelik tutumlarının belirlenmesi. Türkiye Sosyal Arastırmalar Dergisi, 219-232.

Türkiye İstatistik Kurumu. www.tuik.gov.tr. (21.07.2018).

Türk Geriatri Kongresi. http://www.turkgeriatri.org/bildiri_uyh.php. (21.07.2018).

Ünalan, D., Soyuer, F. ve Elmalı, F., (2012). Geriatri merkezi çalışanlarında yaşlı tutumunun değerlendirilmesi. Kafkas Journal of Medical Science, 2, 115-120.

Vefikuluçay, D. (2008). Üniversitede ögrenim gören ögrencilerin yaşl ayrmolhğgna ilişkin tutumlar (Doktora Tezi). Hacettepe Üniversitesi Sağlık Bilimleri Enstitüsü, Ankara.

Vefikuluçay, D. ve Terzioğlu F. (2011). Development and psychometric evaluation of ageism attitude among the university students. Turkish Journal of Geriatrics, 14, 259-268.

Zastrow, C. (2013). Sosyal hiz̧mete giriş (Çev. Edt: D. B. Çiftçi). İstanbul: Nika Yayın.

Zakowicz, I. (2011). The university of the third age and the social exclusion of the elderly. In A. Kobylarek (Edt.). Aging-Social, biological and psychological dimensions (pp. 41-48). Agencja Wydawnicza "Argi", www.argi.pl.

\section{EXTENDED ABSTRACT}

The concept of old age comes into prominence in relation to the aging of the world population and the decrease of the share of the young population in the general population. With this respect, this subject draws attention of academic disciplines (such as medicine, nursing, social work, psychology, sociology, etc.) which work on the field of old age. Aging is thought to be a period of decrease in all vital activities, productivity, self-sufficiency and independent action (Şahin, \& Erdem, 2017). Although there are many definitions of aging and elderly; elderly can be defined as "individuals who experience age-related loss of function and encounter problems in performing daily living activities", and aging can be defined as "the name given to this process".

Elderly discrimination is the other concept that must be considered in this context. It can be defined as having othering attitudes towards aging individuals in the society, thinking that elderly people should live away from society and not respecting the values and attitudes of the elderly people. In other words, in the emergence of elderly discrimination, there are some important situations like inappropriate behaviours towards the elderly, presence of unfair cultural stereotypes, prejudices or fear of the elderly, lack of reliable 
information about old age, the relationship between old age and illness and death, and the changing status of old people in both family and society.

Considering the fact that the elderly population is increasing in our country, it is necessary to increase the individuals who will work in the field of old age and to make more macro-scale studies by evaluating the attitude of elderly discrimination of university students (Özkan, \& Bayoğlu, 2011). The rationale for this study is that, as in the rest of the world, the rate of elderly population in our country has increased gradually; therefore, there may be some changes in the meaning and perspective attributed to the elderly by other segments of the society as well as the problems and needs of the elderly. The importance of the study is to provide a preventive projection in order to determine the perspectives of the young university students who will start working in the fields related to the elderly in various institutions and organizations as well as living together with the elderly in the society. In this context, it is thought to contribute to the current literature.

This study was carried out to determine the attitudes of students of Kirlkkale University Keskin Vocational School on elderly discrimination. The population of the study consisted of students enrolled in Keskin Vocational School in 2017-2018 academic year. In this research, it was aimed to take the whole universe; therefore, no sample selection was made. However, it has been found that the number of students currently attending school is quite low due to the presence of students who have not been active in their education despite the fact that they have been enrolled in the school for a long time, and some programs stop the recruitment.

In this research, it is aimed to measure the social behaviours of individuals and their tendencies towards elderly discrimination objectively through observation and test and to reveal this situation with numerical data. In this context, it is planned to reach the maximum number of the study group by taking into account the representation of the universe about the subject investigated in the quantitative research method. Therefore, the data collection process was carried out with 322 students. The causal-comparison model was used to compare the differentiating groups in terms of a variable (gender, age, department...) from quantitative research models. After the literature review by the researchers, the personal information form consisting of 10 questions and the "Attitude Scale for Elderly Discrimination" (YATÖ) consisting of 23 questions were used as data collection tools. Data were collected by face to face interview. In accordance with the nature of the quantitative research design, statistical results such as relationships and differences were investigated.

When the results that make a statistically significant difference are analysed, it is determined that the gender of the students and the programs enrolled make a difference on the attitudes of individuals towards elderly discrimination. It has been found that male students have more positive view towards the elderly. However, it was found that there was no statistically significant difference in terms of other variables (age of the students, family type, and the best understood family member and their opinion about where to stay). This indicates the existence of intergenerational relations and shows that the social, cultural and economic relations between the elderly and other groups continue. In order for this communication to produce better results, the elderly need to be open to the innovations and changes of the modern world, to have a positive perspective, to maintain their personal development, to have curiosity and activation, to have creative problem solving skills and to have sharing characteristics. On the other hand, a generation away from the negative point of view, suggesting the positive aspects of old age, struggling with prejudices, seeing old age as a value and seeing them in a dignified position in the social structure should be targeted in order to reduce the elderly discrimination to a minimum level (Zakowicz, 2011, p. 47). 